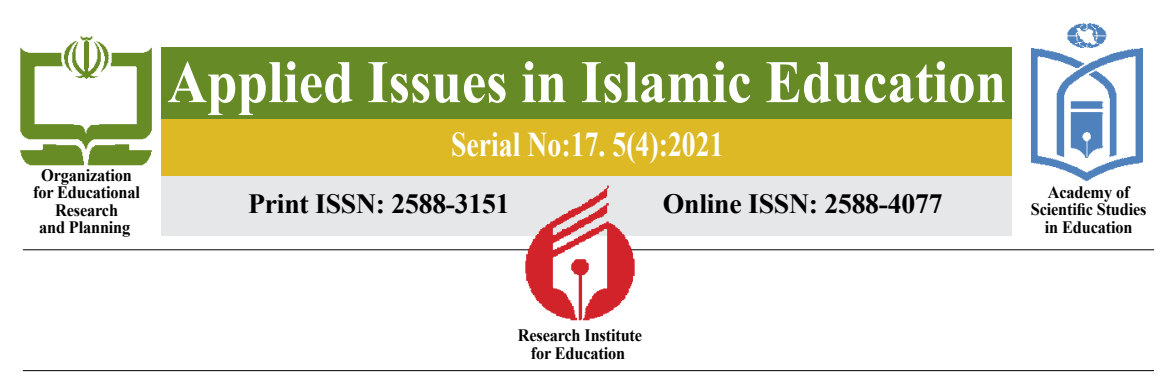

\title{
Identifying the Motivating Components of the Khamsa 'Ashar Supplication on Students' Intimate Relationship with Allah
}

\author{
-Mohammad-Taqi Mobasheri ${ }^{1} \quad$ Mahmood Safari ${ }^{2} \quad$ Maryam Malefi Farmad $^{3}$
}

- Objective: The purpose of this study was to identify the motivating components of Khamsa'Ashar supplication on students' intimate relationship with Allah.

- Method: The statistical population of the study consisted of female high school students in the Tabadakan region of Mashhad in the academic year 2019-2020, and consisted of about 6150 students, and 360 students were selected as a sample through simple random sampling according to Morgan's table. This research method was a mixed one in terms of implementation (qualitative-quantitative). In order to analyze data in the qualitative section, the text of the Khamsa'Ashar supplication was studied using NVivo10 quality software, and then the components affecting human's intimate relation with Allah were identified through open and central coding. Also, based on the extracted components, a 32-item researchermade questionnaire with a 5-point Likert scale was developed. The face and content validity of the questionnaire were confirmed by expert professors. The reliability of the questionnaire was calculated to be 0.935 Cronbach's alpha. In the quantitative part, for data analysis, descriptive and inferential statistics including Cronbach's alpha, extracted mean-variance, the mean root of extracted variance, KolmogorovSmirnov, exploratory factor analysis, confirmatory factor analysis, SP1, and single sample t-test through the NVivo10, SPSS24, and Smart-PLS software were used.

- Finding: The results showed that the four components of 'one's own right', 'Allah's right', 'people's right', and 'Infallibles' right' extracted from the Khamsa ' Ashar supplication have a positive effect on the intimate relationship of female students with Allah.

- Conclusion: Thus, inclusion of the supplication in the textbooks can be effective in the students' intimate relation with Allah.

Keywords: relationship with Allah, Allah's right, infallibles' right, people's right, Khamsa'Ashar, students.

Citation: Mohammad-Taqi Mobasheri., \& Mahmood Safar., \& Maryam Malefi Farmad. (2021). Identifying the Motivating Components of the Khamsa 'Ashar Supplication on Students' Intimate Relationship with Allah. Applied Issues in Islamic Education, 5(4): 109-126.

Received: $2021 / 01 / 03$

Accepted: 2021/02/17

1. Corresponding Author: An Assistant Professor, the Department of Theology and Islamic Studies, Farhangian University, Tehran, Iran.

E-mail: Mt_mobasheri@yahoo.com. (iD 0000-0001-9580-6637

2. An Assistant Professor, the Department of Educational Sciences, Farhangian University, Lamerd, Iran.

E-mail: Drsafari2016@gmail.com. (D) 0000-0002-9119-7732

3. MA in the Quranic and Hadith Sciences, Farhangian University, Tehran, Iran.

E-mail: Maleki.forat313@gmail.com. (D) 0000-0003-2574-2265 


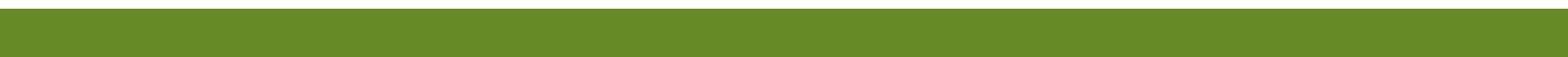



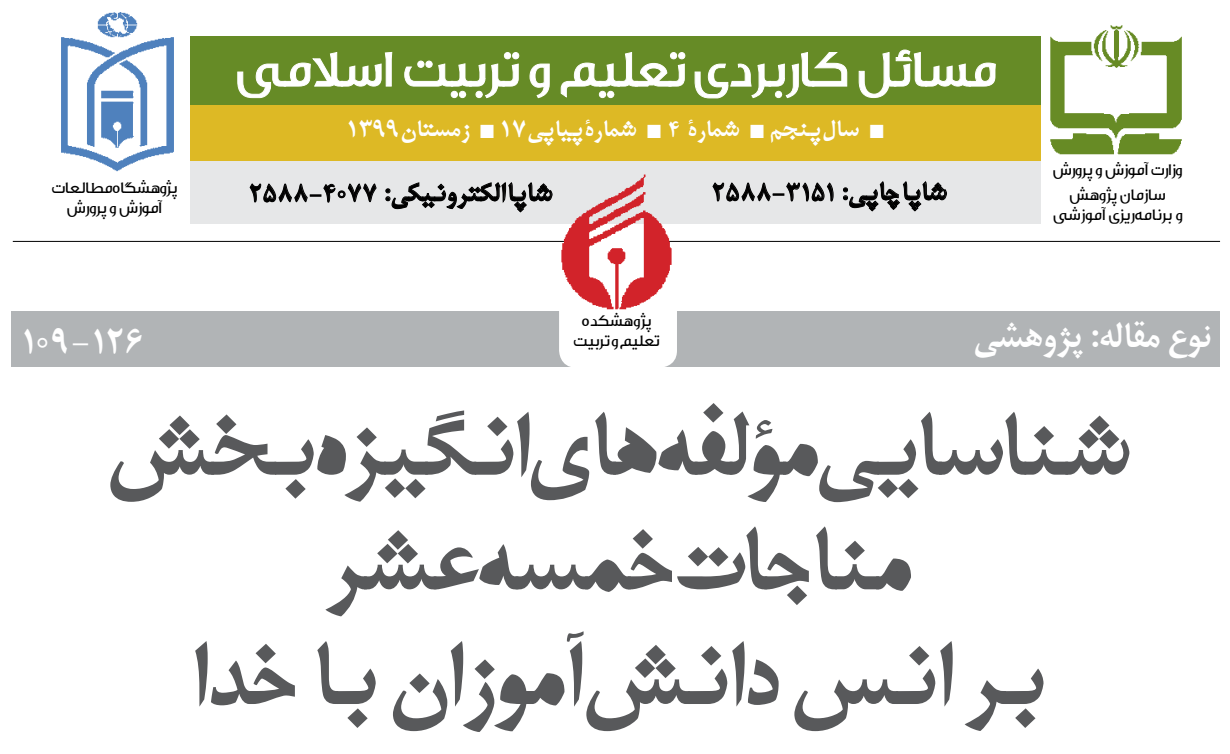

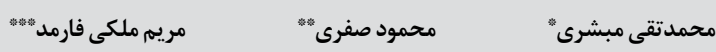

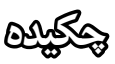

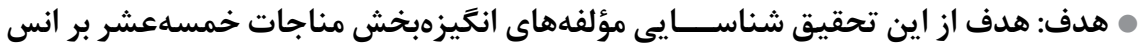

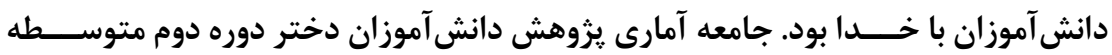

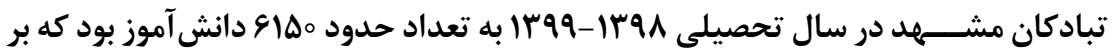

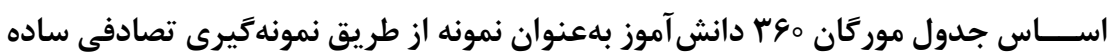

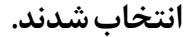

• روش: ايـــن تحقيق از نظر هدف كاربردى و از نظــــــ اجرا آميخته (كيفى -كمى) بود. بهنظر

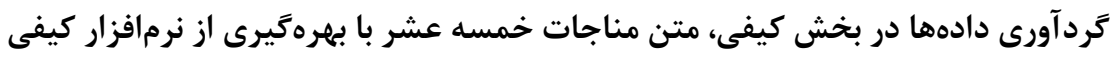

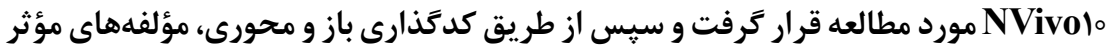

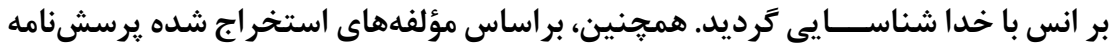

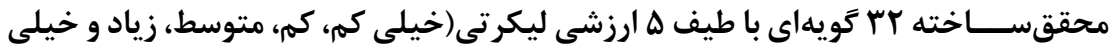

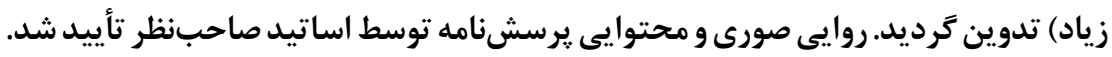

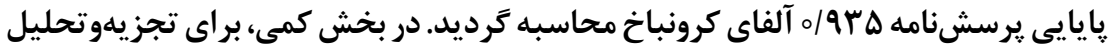

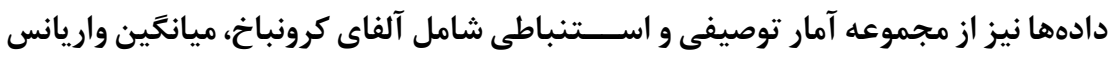

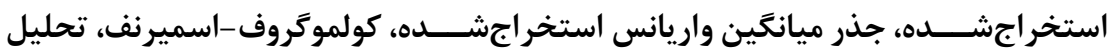
४

* نويسنده مسئول: استاديار كروه الهيات و معارف اسلامى، دانشكاه فرهنَّيان، تهران، ايران.

Email: Mt_mobasheri@yahoo.com (iD 0000-0001-9580-6637

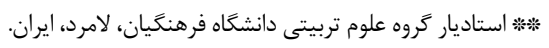
Email: Drsafari2016@gmail.com (ID 0000-0002-9119-7732

" Email: Maleki.forat313@gmail.com (D) 0000-0003-2574-2265 


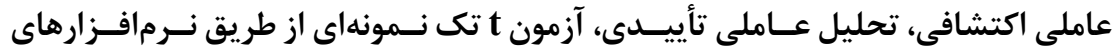

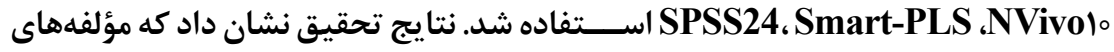

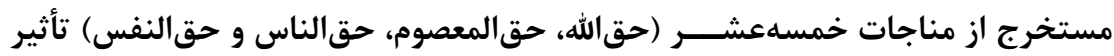
بهسزايى در انس دانش آموزان دختر با خدا دار مارد.

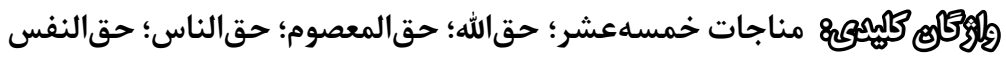

\section{مقدمه}

"ادعا داراى مفهوم عام و معنايى گسترده است و شامل خواستن با هر زبان و كيفيتى است كه توجه به دو نكته در آن ضرورى به نظر مىرسد: الف) وادى دعا و مناجات، وادى القاى معارف گوناگون دين است. ساحت ادعيه تنها اين نيســت كه انســان در دعا يا مناجات با خدا حالت عاطفى ثيدا كرده، دلش بسوزد و اشكش جارى گردد و از عمق حقايق توحيدى و معرفتى آن غافل باشد. تحصيل و حفظ حالات عاطفى بلويزه در مقام خواندن دعا و مناجات لازم اســت، اما هر زز نبايد به اين بعد بســـنده شود، بلكه بسيار ضرورى است كه به بعد علمى بيان معارف دينى ادعيه نيز با دقت توجه شود. ب) بايد راهكارهاى عملى و تربيتى موجود در ادعيه اســتنبـاط و تحليل و آن گاه در ســير عملى و اخلاقى اجرا شود. بهعنوان نمونه، اخر واقعيتى درباره اثر زناه، ضمن دعاو مناجات بيان مى شـــود، راهكار يرهيز و شستوشوى آلودگى گناه نيز از دعا يا مناجات استفاده شده، در عمل به كار گرفته شود (تحريرى، \ه | ).

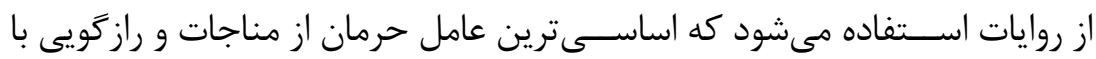
خدا و عدم درك لذت كفتو كوى با خدا، تعلق و وابســتخى به دنيا و لذتهاى آن است. وقتى انســان حاضر مىشود از لذتى دست بكشد كه به لذتى فراتر از آن دست يابد، آر

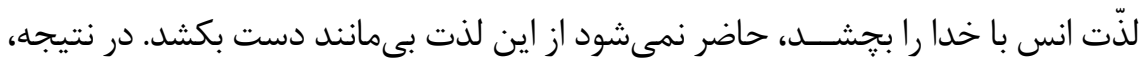
لذتهـــاى يوج و بـىمقدار دنيا راوامــى نهد. در حقيقت، محبت به خدا و انس با او مانع

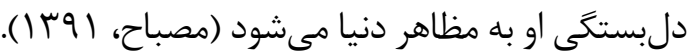
لذا انســان، مستعدّ اتصاف به همه كمالات اســت. اما وصول به آنها، در زرو تربيت 
صحيح مىباشد و براى رســيدن به قربالىالله، بايد بهترين شيوهها را انتخاب نمود. به يقين، برترين روشها كه مبتنى بر شـــاخت حقيقت انسان و همه ابعاد وجودى اوست، تنها در كلام و سيره انسانهاى كامل در هر عصر و زمان جستوجو مىشود كه كسى جز

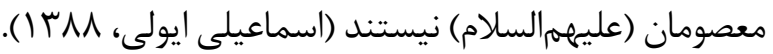

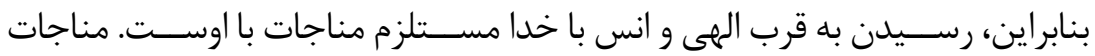
زمزمهايسـت بين عاشق و معشوق؛ سرّى كه زينالعابدين (عليهالسلام) از عمق وجود با يرورد گار متعال مطرح مى كند. مناجاتهاى زينت عبادت كنندگًان، سيّد سجده كنند فانى جانسوخته و امام دلباخته، حضرت علىبنالحسين (عليهالسلام) با عنوان مناجات خمسهعشر، خداى خويش را عارفانه مى خواند و به مؤمنين آموزش مى دهد كه جُكونه با ربّ عالميان، سخن كنند. مناجات اخمسهعشر " مجموعهاى از يانزده مناجات بسيار زيبا، غنى و سراسر معنويت است كه بخشــى از درياى بيكران ادعيه به جا مانده از حضرت امام سجاد (عليهالسلام) مىباشـــد. اين دعاها نشاندهنده روش آن حضرت در شرايط خاص سياسى، اجتماعى و فرهنكى آن دوران است كه با كياست خاص و با زبان دعاو نيايش، ادامه مسير هدايت و امامت را براى مؤمنين، تبيين و روشن فرمودند. مجلسى (Y F F اق) به سالكان الى الله توصيه مىنمايد كه بر خواندن مناجات خمسهعشر

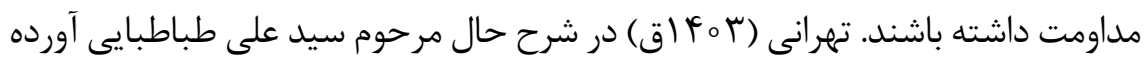
اســت كه ايشان فرموده: من جنـلين سال است كه برقرائت / ين مناجات مداومت دارم و بــر اثر قرائت / ين مناجاتها، خداوند بر قلب من انوار حكمت، معرفت و محبت را تابانده اســت بهصورتى كه قابل شمارش نيست و من /ين مناجاتها را در استجابت دعا تجربه نمودهام. ايشــان در ادامه به سالكان و عبادت كنـند ان توصيه نمودهاند كه بر قرائت اين مناجات مداومت داشته باشند

مصباحيزدى (| qج|) معتقد است انسان با مطالعه اين مناجات، از فقر ذاتى و شدت نياز خود به خدا آحاه مىشود، نيازهايى كه كمتر بدانها توجه مىشود. ايشان مى گويد: نيازهاى اصيل و اساسى انسان، نيازهاى متعالى معنوى و انسانى است كه اساساً آفرينش او به هدف دستيابى به آنها انجام يذيرفته است و نيازهاى مادى و حيوانى در قبال اين 
براى خواندن مناجات خمس عشـــر نظمى تعريف شده است. جوادى آملى (؟ ا I ) معتقد است نظم تدوينى مناجات خمسعشر قابل تأمل است و عالمان اخلاق بايد نظم اين مناجاتها را سامان دهند. وى معتقد است: جُنانكه نظم تدوينى برخى ادعيه نيز قابل تأمل اســت مثلا اولين مناجات از "امناجات خمس عشره/ كه از امام سجاد(ع) نقل شده در ترتيب كنونى آن "مناجات تائبان "و آخرين آن "مناجات زاهدانه است. در حالى كه

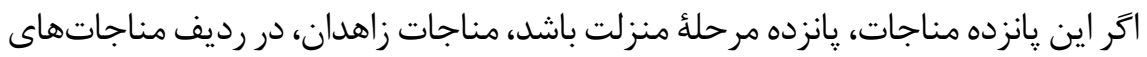
اوليه اســت، نه آخرين مناجات. يعنى انسان، نخســت توبه مى كند و زهد مىورزد و از رذايل مىرهد و ســـــ به فضايل بار مىيابد كه عالى ترين فضيلت، به لقاءالله و بالاتر از آن لاحبالله است. فهرسـت اين مناجات عبارتند از: مناجات تائبين (مناجات توبه كنند شــاكين (شـــكوه كنـندان)، خائفين، راجين (اميدواران)، راغبين (مشتاقان)، شاكرين (سياســَزاران)، مطيعين (فرمانبــرداران)، مريدين (اهل ارادت)، محبّين (دوســتـان)، متوسلين (توسلجويان)، مفتقرين (نيازمندان)، عارفين (عارفان)، ذاكرين (يادكنند حق)، معتصمين و مناجات زاهدين (يارسايان) است. اخر جه مناجات خمسهعشره بهلحاظ

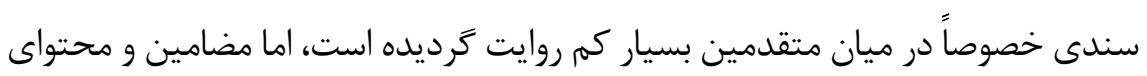
بلند اين مناجات آنقدر شيوا و بليغ و زيبا مطرح گرديده كه خود نشاندهنده اين است كه اين جملات عارفانه جز از ائمه اهلبيت بر نمى آيد. حضرت در "مناجاتالتائبين "به آثار سوء گَناهان يرداخته و راه جبران و برونرفت از نتايج گَناه را توبه معرفى مىفرمايند. در "امناجاتالشاكين "خطر نفس امّاره را تذكر داده

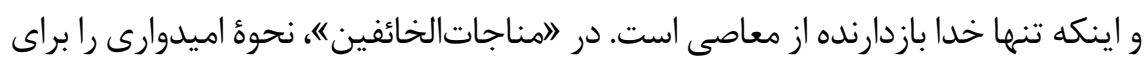
انســان رونمايى مىفرمايند و در "امناجاتالراجين" نتيجه اخلاص حقيقى را اطمينان

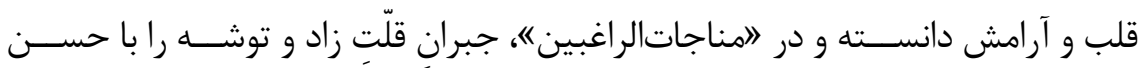

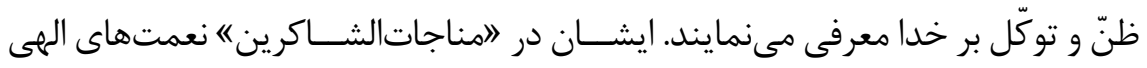
را يادآورى و فضل و رحمت حق را غيرقابلشــمارش مى دانند. در "امناجاتالمطيعين" لــــت حقيقى را در مناجات با معبود و تقربالى الله معرفى مىفرمايند. سيّدالسّــاجدين

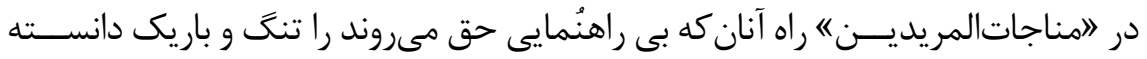

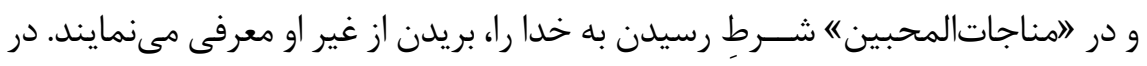


"امناجاتالمتوسلين شـــاعت نبى اكرم (صلواتاللهعليه) را جلوه رحمت و رأفت الهى دانســته كه بدون آن ســير و صعود ممكن نيســت. امام در "امناجاتالمفتقرين" عزت حقيقى را در يذيرش عزت و ســلطنت خداوند دانسته و در "امناجاتالعارفين" معرفت حقيقى به خدا را موجب شــرح صدر معرفى مىنمايسـد. حضرت در "مناجاتالذاكرين" متذكر مى شـــوند كه توجه انسان نسبت به خدا، به اندازه سعهُ وجودى اوست، نه ميزان شـأن خدا. در "مناجاتالمعتصمينه به ما مى آموزاند كه تنها فقرى كه يســتى و ذلت نمى آورد، فقر نســبت به خداست و در نهايت زينت عابدان در "امناجاتالزاهدين" به ما مىنمايانند كه دنيا، گردابى مخوف است كه با مكر و فريب، غافلان را در خود فرو مىبرد. زينتش بـىنكبت و نوشــش بىنيش نيســت، وس افراد صالح كسانى هستند كه خداى

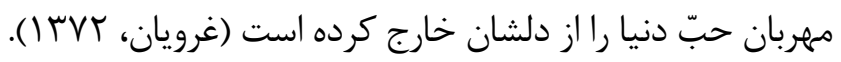
بنابراين، دغدغه محققان از جايى شروع شد كه متوجه كمرنت شدن انس دانش آموزان با خدا و اهميت مناجات با خدا شـــند. لذا مناجات خمسهعشر را مورد توجه قرار دادند تا زمينه انس شاگردان با خدا را ارتقاء دهند. از طرفى، براى اين كه انسان بتواند با خداى خويش به درستى انس بخيرد، نيازمند انخيزه است.

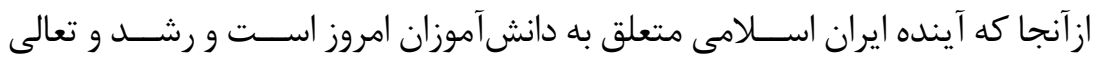
دانشآموزان در زرو شناخت صحيح و دقيق نيازهاى آنان است، تا با يرورش استعدادهاى به وديعه حذاشته شده، زمينهُ تعالى آنان و همجنين تعالى ايران عزيز فراهم شود، ضرورى اســت به اين بُعد از ابعاد تربيتى توجه ويزه گَــردد. علىرغم وجود كتابهاى هديههاى آســمان و دين و زندگى در دورههاى مختلف تحصيلـىى، اهميت انس و مناجات با خدا برجســته نشــده و حتى انس با خدا در بين دانشآموزان كمى كمرنتَ شده است؛ لذا در ايسـن يزوهش مناجات خمسهعشــر مورد توجه قرار زرفت تا با نشــان دادن ديد دانشآموزان جامعه آمارى، متوليان امر تدوين كتب درسى را به اين مهرم توجه دهد تا از

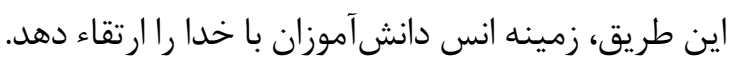

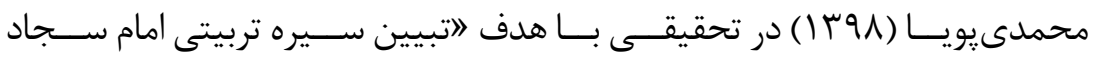
(عليهالســلام) در صحيفه سجاديه با تأكيد بر ســند تحوّل بنيادين آموزش و يرورشيـي دريافت كه امام سجاد (عليهالسلام) به تمام ساحتهاى تربيت آدمى (اعتقادى، عبادى و اخلاقى، اجتماعى، سياسى، زيستى و بدنى، اقتصادى، حرفهاى، زيبايىشناختى، هنرى، 
علمى و فناورانه) توجه داشــتهاند و از همينروو مىتوان ســيره تربيتى ايشان را بهعنوان اسوهاى حسنه، نهتنها در نظام تعليمى و تربيترسمى كشور بلكه در هويتبخشى به سبك زندگى افراد جامعه، بلهمار آورد.

خسروى (وq | () در يثروهشى با هدف لاتبيين شاخصههاى بنده آرمانى در مناجات

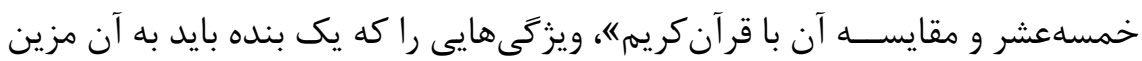
باشـــد اســتخراج نموده و آن را با آنجه در قرآن كريمم تحت عنـــوان صفات لامتقينه، "اعبادالرحمان " و "صالحان" آمده است تطبيق داده تا علاوه بر اثبات الهى بودن كلام امام، بهعنوان راهكار عملى تقرب به معبود براى جويند

ســازجينى و فرجى (Dه ||) در يزوهشى با هدف لابررسى ادعيه قرآنى در مناجات

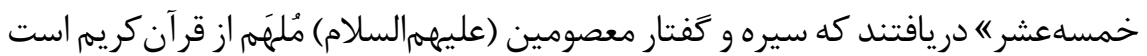
و به نمونههايى از تجلى ادعيه قرآنى و هماهنگى مفاهيم مناجات خمسهعشـــر با آيات

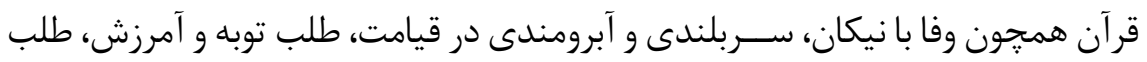
رحمت المىى، ييروزى بر كافران، تسبيح و تحميد خداوند، درخواست دور ماندن از عذاب الهى و متتعمم بودن در بهشت دست يافتند. ايرانمنش و رستمىنســب (هوس|) در تحقيقى با هدف لاتبيين روشهاى تربيت عقلانى در صحيفه ســـاديه" دريافتند، تعليمروتربيت با رشد و كمال انسان و زندكى شايســته او سر و كار دارد. از آنجا كه انسان موجودى است پيجزيده، تعليمم و تربيت او نيز ييجِيده و مســـلزم تمهيد مقدمات فـــراوان و بهره گيرى از روشهاى تربيتى مؤثر است. بدينروى براى ساماندهى به تعليمورتربيت، بايد از منابع غنى و با ارزشى همجون

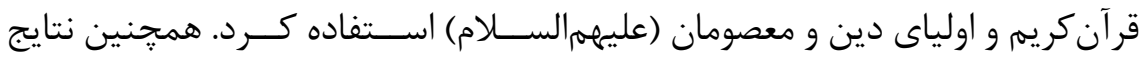
يزوهش آنها بيانگر اين اسـت كه ســخنان حضرت زينالعابدين جايگاه فوقالعادهاى براى انســان قائل اسـت و به هميندليل برنامهها و روشهاى تربيتى مطمئنى براى إى تربيت و ســـادت و رستخارى بشـــر همجون روشهاى تربيت عقلانى از جمله تزكيه،

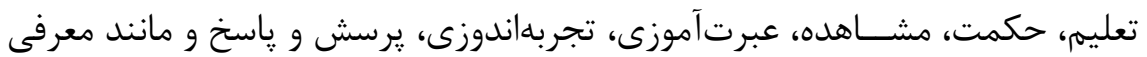
مى كند.

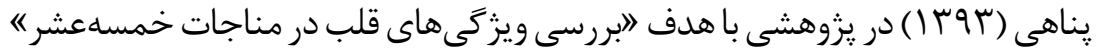


دريافت خوف و رجا، قبض و بســـط، ايمان و اطمينان، ذكــــر و الهام، ويزگَى هاى مثبت قلب بوده و موت، قســاوت، رَين، طبع، ختهم و حجاب، ويزگَى هاى منفى قلب هســـنـد.

بدخشــان ( اqس|) در مطالعهاى با هدف لاتبيين توبه از نــاه عقل و نقل با مرورى بر صحيفه ســاديه" دريافتند هر انسانى با قرار گرفتن در هر مرتبهاى از كمال، بركنار از

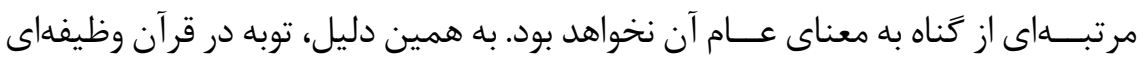
همعًانى معرفى شده است. از منظر دينى هرجند شايسته است انسان در حد توان خود از ارتكاب به گَناه بيرهيزد، ولى جُنانجه مرتكب گَناهى شــد، راه برونرفت از آن، توبه و استغفار است. اسماعيلى ايولى (INAN) در يزوهشى با هدف لابررسى روشهاى تربيتى در سيره امام سجاد (عليهالسلام) هريافت رسيدن انسان به همه كمالات در زرو تربيت صحيح مىباشد و براى رسيدن به هدف والاى قرب الهى بايد بهترين شيوهها را انتخاب نمود كه مبتنى بر شـــناخت حقيقت انسان و همه ابعاد وجودى او باشد. بنابراين، جنين روش هايى تنها در كلام و راه انسانهاى كامل در هر عصر و زمان جستجو مىشود و جنين انسان هايى براى همه عصرها و زمان ها جز معصومان (عليهمالسلام) كسى نيست. فلاحيور ( ) ( ) در تحقيقى با هدف اتبيين روشهاى تربيتى امام سجاد (عليهالسلام)《، دريافت هدف از تربيت؛ عبادت حق و در نتيجه شناخت خداوند است. تربيت خلق، فلسفه بعثت رسولان و مهممترين وظيفه اولياى الهى است. همجنين به اين نتيجه رسيدند كه اهداف تربيتى دوران رهبرى امام ســجاد (عليهالســلام) از قبيل هدايت به حق و تميز از باطل، اصلاح جامعه اسلامى و رسيدن به حيات طيبه، از طريق روشهاى تربيتى مبتنى بر عقل و وحى از جمله حفظ و تقويت عزت و كرامت افراد، تغافل، عفو و محبت محقق مىشود.

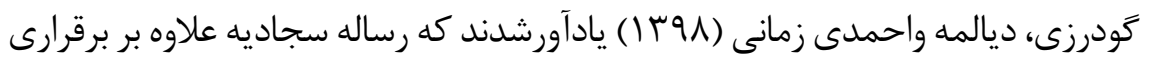
انس با خدا در مســئوليتيذيرى دانشآموزان در فرايند آموزشى بسيار مؤثر و تأثير زذار است. غلامى و مشهدىزاده (99 (1) ياد آور شدند كه رساله امام سجاد به دليل تأثيرات زيادى بر آكاهىهاى دانشآموزان از حقوق شــهروندى دارد بهطور غيرمستقيهم بر انس و گرايش به معنويت و ذات احديت تأثير دارد. نتايج مطالعات انجام شــده نشان مى ندهد كه در اين زمينه يروهش هاى مستقيمى و هدفمندى ييرامون مؤلفههاى انخيزهبخش انس با خدا بهويزه در مناجات خمسهعشـر صورت نكرفته است. لذا ير كردن خلاء مطالعاتى 
ايــن تحقيق از نظر هدف كاربردى و از نظـــــر اجرا آميخته (كيفى_كمى) بود. جامعه

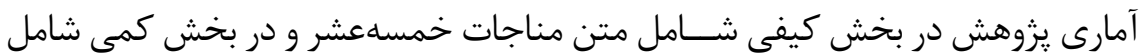

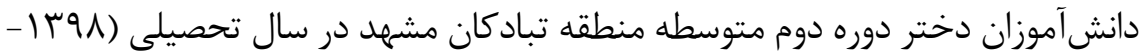

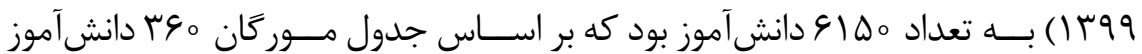

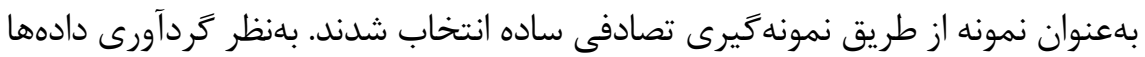
در بخش كيفى، متن مناجات خمسهعشر با بهره

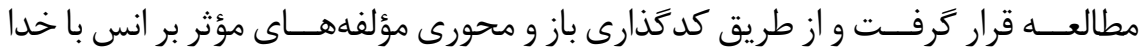

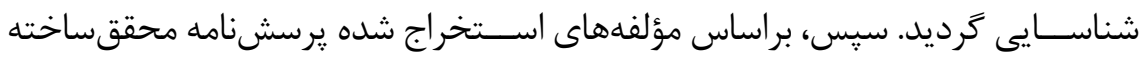

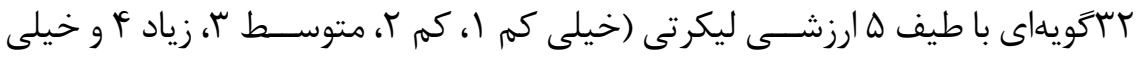

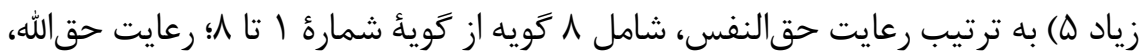

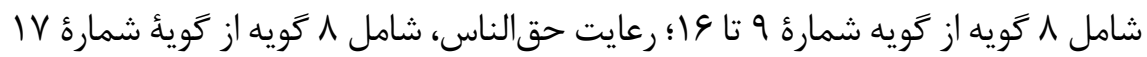

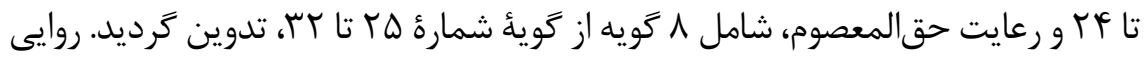

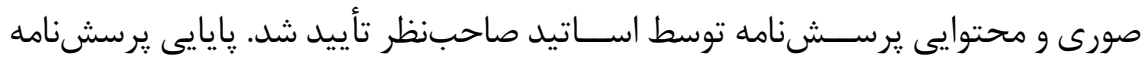

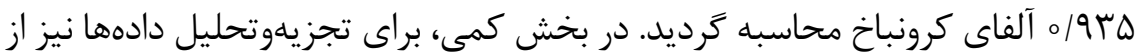

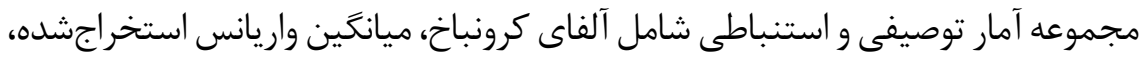

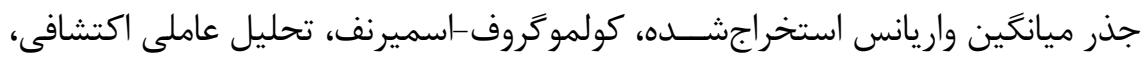

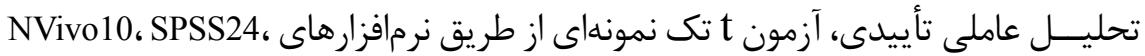

Smart-PLS

\section{يافتهها}

سؤال اول: مؤلفههـاى انكيزهبخش دعاى خمسهعشر در انس دانش آموزان با خدا

كدامند؟

براى ياسخ به اين سؤال ابتدا مبانى نظرى و پِيشينه تحقيق مورد مطالعه قرار گرفت،

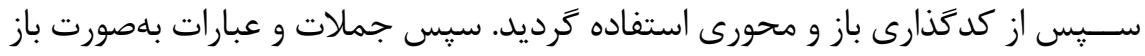

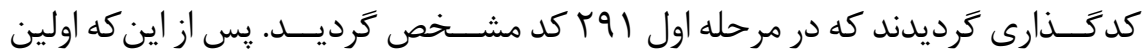

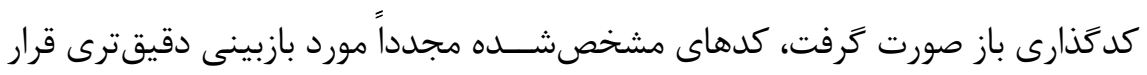




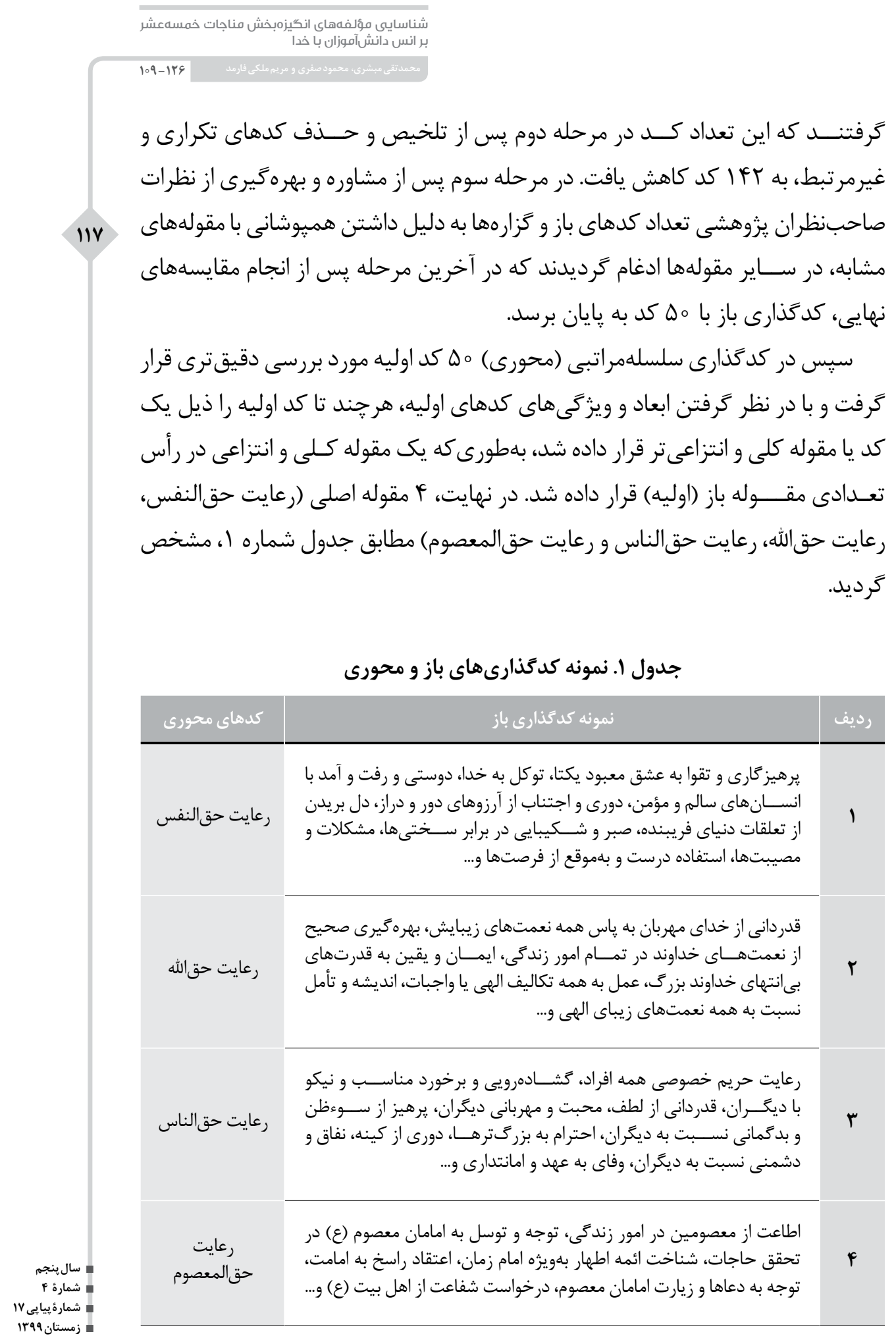




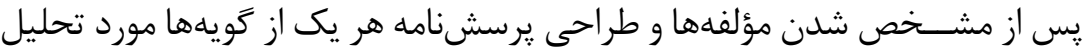

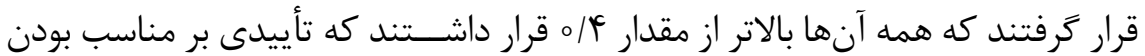
دادهها و تحليل عاملى بود. در نهايت، تحليل عامل اكتشافى (روش تحليل مؤلفه اصلى)

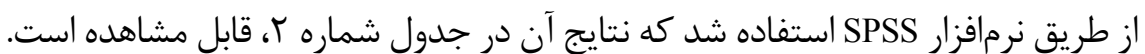

\section{جدول r. خلاصه نتايج روايى واكر ا براى مؤلفها}

\begin{tabular}{|c|c|c|c|c|}
\hline رعايت حقالمعصوم & رعايت حقالناس & رعايت حقالله & رعايت حقالنفس & مؤلفهها \\
\hline & & & $\circ / \Lambda \circ f$ & رعايت حقالنفس \\
\hline & & $\circ / \Lambda \mid f$ & $\circ / 014$ & رعايت حقالله \\
\hline & o/Arq & o/TGY & $\circ / \Delta||$ & رعايت حقالناس \\
\hline O/ATY & $\circ / \mathcal{F} \circ \circ$ & $0 / 419$ & o/DHF & رعايت حقالمعصوم \\
\hline
\end{tabular}

همانطور كه در ماتريس بلهدسـت آمده در جدول شماره ؟r، مشاهده مىشود، مقدار جذر هر يك از عوامل از ضرايب همبســتخى آن با عوامل ديخًر بيشتر شده است كه اين امر حاكى از قبول بودن روايى واگراى عوامل جهار گانه مىباشد. جدول r. شاخصهاى نيكويى برازش مدل

\begin{tabular}{|c|c|c|c|c|}
\hline نتيجه & حل مجاز & \multicolumn{2}{|c|}{ بو آوروهـا } & نام شاخص \\
\hline \multirow{2}{*}{ غيرقابل قبول } & \multirow{2}{*}{$P>\circ / \circ \Delta$} & \multicolumn{2}{|c|}{$=\vee 9.1 \Delta \Delta$} & \multirow{2}{*}{ مجذور كاى } \\
\hline & & $\mathrm{P}=000.0$ & $\mathrm{df}=\Lambda \mathrm{r}$ & \\
\hline قابل قبول & كمتر از ه & \multicolumn{2}{|c|}{$\Lambda N / 1$} & مجذور كاى بر درجة آزادى \\
\hline غيرقابل قبول & كمتر از ^^/。 & \multicolumn{2}{|c|}{01099} & 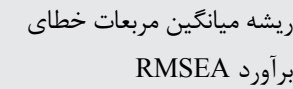 \\
\hline قابل قبول & بالاتر از 9/9 & \multicolumn{2}{|c|}{$0 / 91$} & نيكويى برازش GFI \\
\hline قابل قبول & بالاتر از 9/ه & \multicolumn{2}{|c|}{$0 / 99$} & برازندگى نرم شده NFI \\
\hline قابل قبول & بالاتر از 9/ه & \multicolumn{2}{|c|}{.$/ 9 V$} & برازندگى نرم نشده NNFI \\
\hline غيرقابل قبول & كوخكتر از هـ/。 & \multicolumn{2}{|c|}{$\%$ Fa } & $\begin{array}{r}\text { ريشه ميانگين مربعات باقيمانده } \\
\text { SRMR SRM }\end{array}$ \\
\hline قابل قبول & بالاتر از 9/ه & \multicolumn{2}{|c|}{$\circ / 91$} & برازندگى مقايسهاى CFI \\
\hline
\end{tabular}


با توجه جدول شــماره ؟، شاخصهاى نيكويى برازش مدل نشاندهنده برازش قابل قبول براى مدل مىباشد.

جدول F. مقادير ويزه، درصد واريانس و درصد واريانس تراكمى عاملهاى استخراجشده

\begin{tabular}{|c|c|c|c|c|c|c|}
\hline \multicolumn{3}{|c|}{ مجموع مجذورات بعد از جرخش واريماكس } & \multicolumn{3}{|c|}{ مقادير ويثره } & \multirow{2}{*}{ مؤلفه } \\
\hline 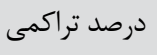 & درصد واريانس & مقدار ويزه & درصد تراكمى & درصد واريانس & 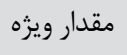 & \\
\hline rd/RTr & rd/RTr & IIFA & $r \Delta / V T r$ & $\Delta \Delta \mu \Delta / V M r$ & II/אU & 1 \\
\hline$F \Delta / \circ q V$ & १/१९५ & r/994 & $F \Delta / \circ q V$ & q/ץq & T/99४ & $r$ \\
\hline D०/9६r & $\Delta / \wedge ৎ \Delta$ & I/AVV & $0 \circ / 994$ & $\Delta / \wedge \notin \Delta$ & I/AVV & $r$ \\
\hline \multirow[t]{3}{*}{$\Delta \varphi / \Delta \varphi \Delta$} & $\Delta / 9 \circ r$ & 1/V9r & $\Delta \varphi / \Delta \varphi \Delta$ & $\Delta / 9 \circ r$ & 1/V9r & f \\
\hline & & & GO/OTY & $r / F \varphi_{0}$ & o/ANT & $\Delta$ \\
\hline & & & $94 / 091$ & 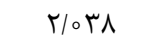 & O/AYO & 9 \\
\hline
\end{tabular}

جنانكه در جدول شماره F ديده مىشود، ارزش هاى ويزه F عامل بزرت تر مساوى يك

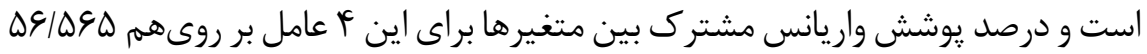
درصد كل واريانس متغيرها را تبيين مى كنند. بهعبارتديخر، جنانجه از مجموعه گويهها

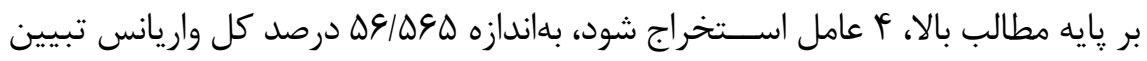

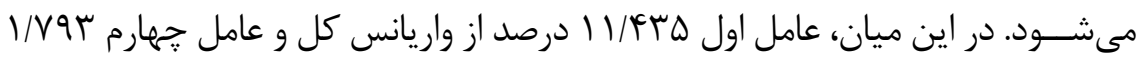
درصد از واريانس مشترك را توجيه مئ كند.

سؤال دوهم: ميزان تأثير هر يـــ از مؤلفههــاى انـحَيزهبـخش مناجات خمسهعشر بر انس

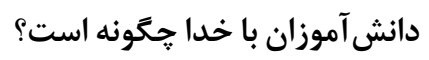
جدوله. بار عاملى و مقادير t مؤلفههاى اثربخش بر »انس با خدا《

\begin{tabular}{|c|c|c|c|c|c|}
\hline نتيجه & P-Value & سطح قابلقبول & مقدار t & بار عاملى & عامل \\
\hline عالى & $p<0 / \circ \Delta$ & $t>1 / 94$ & TY/VqI & o/ArV & رعايت حقالنفس \\
\hline 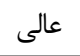 & $p<\circ / \circ \Delta$ & $t>1 / 99$ & $p V / 009$ & $0 / 190$ & رعايت حقاله \\
\hline عالى & $\mathrm{p}<\circ / \circ \Delta$ & $t>1 / 99$ & TN/TYV & o/Arq & رعايت حقالناس \\
\hline عالى ع & $\mathrm{p}<0 / 0 \Delta$ & $t>1 / 94$ & $\Pi 1 / \tau V_{0}$ & $\circ / 1 \Delta 9$ & رعايت حقالمعصوم \\
\hline
\end{tabular}


همانطور كه جدول شــماره ه نشــان مىدهد ميزان تأثير هر يــك از مؤلفههاى

انخيزهبخش دعاى خمسهعشر بر انس به خدا به ترتيب به شرح ذيل مىباشد:

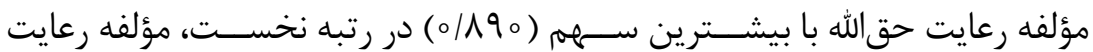

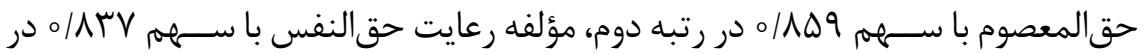
رتبه سوم، مؤلفه رعايت حقالناس با سهم AY9/ه در رتبه آخر (جهارم) قرار زرفت.

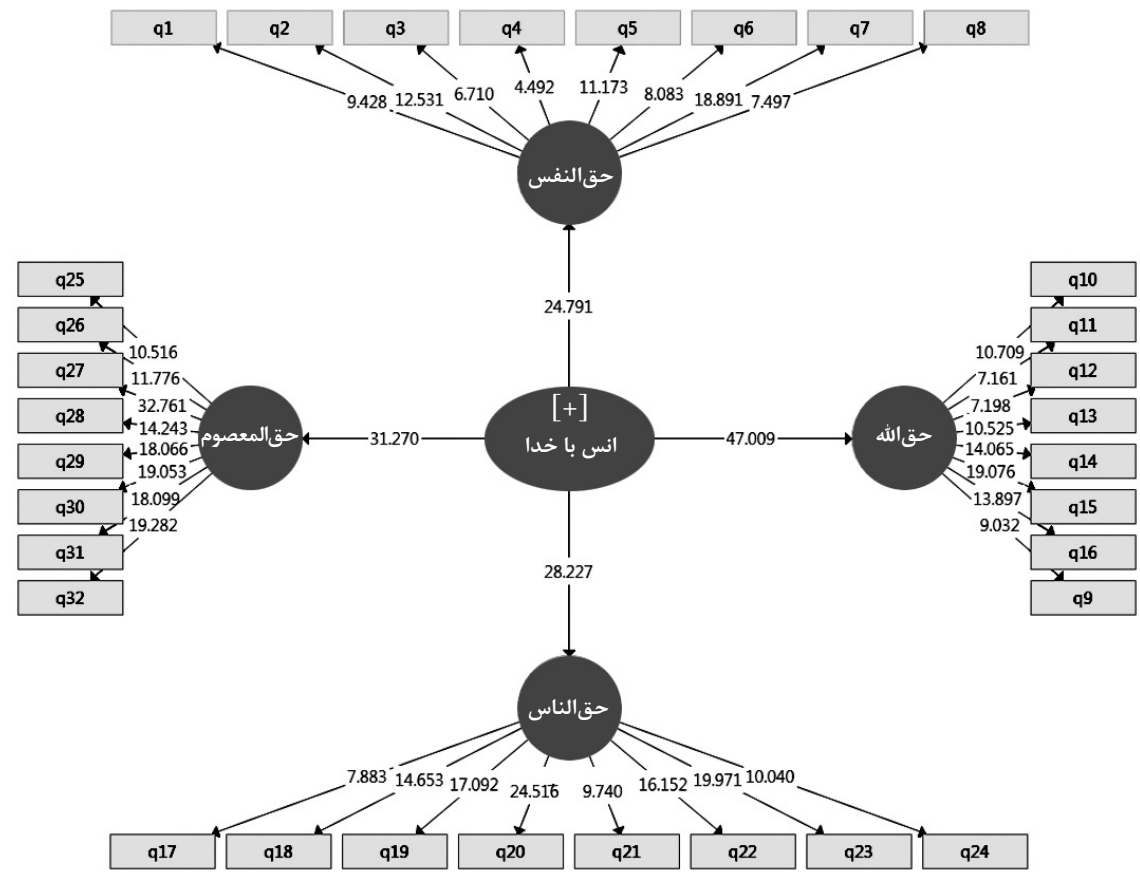

نمودار ا. مدل تحليل عاملى تأييدى مؤلفههاى انغيزهبخش دعاى خمسهعشر بر انس

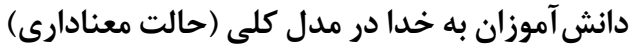

همانطور كه در نمودار شماره ا نشان دادهده است، مقادير آماره t بهدست آمده در

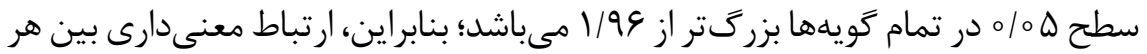
يك از مؤلفههاى انخيزهبخش دعاى خمسهعشر بر انس دانش آموزان به خدا بهعنوان مدل

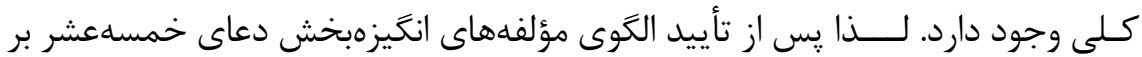
انس دانشآموزان به خدا مىتوانيم دريابيم كه جهار مؤلفه شناسايىشده، نقش به سزايى را در انس دانشآموزان به خدا ايفا مى كنند. 
شناسايي مؤلفههاي انكيزمبخش مناجات خمسهعشر

بر انس دانشآمؤلفوزان با خدا

$109-1 \% 9$

جدول 9. شاخص بررسى كيفيت ابزارهاى اندازهكيرى مؤلفههاى انگيزهبخش بر انس دانش آموزان به خدا اندا

\begin{tabular}{|c|c|c|c|}
\hline 1-SSE/SSO & SSE & SSO & مؤلفهها \\
\hline $0 / r \Delta 9 \Lambda 1$ & $\Delta 9 r / / \Delta \Delta \Lambda_{0}$ & 1०。 & رعايت حقالنفس \\
\hline O/ETVGA & $F \Delta V / \Lambda \Delta V V V$ & 1०o & رعايت حقالله \\
\hline - MFAIA & $\Delta r r / A \Delta F \circ q$ & 1.o & رعايت حقالناس \\
\hline o/TfFAT & $\Delta T F / T V V \Delta T$ & 1.o & رعايت حقالمعصوم \\
\hline
\end{tabular}

همان طور كه جدول 4 نشان مىدهد، مجموع مربعات مشاهدات (SSO) و نيز مجموع مربعــات خطاهاى ييشبينى (SSE) براى هر بلــوك متغير مكنون داراى ضريب مثبت مىباشد و نشان مى دهند كه مقادير مشاهده شده خوب بازسازى شدهاند و مىتوان نتيجه كرفت كه مدل ساختارى مؤلفههاى انخيزهبخش دعاى خمسهعشر بر انس دانشآموزان به خدا از كيفيت مناسب برخوردارند. بنابراين مدل ييشنهادى انس دانش آموزان به خدا بر اساس مؤلفههاى شناسايىشـــه بلهورت شكل شماره ا، ارائه مي گردد، بهطورى كه سهم هر يك از عوامل هم مشخصشده است.

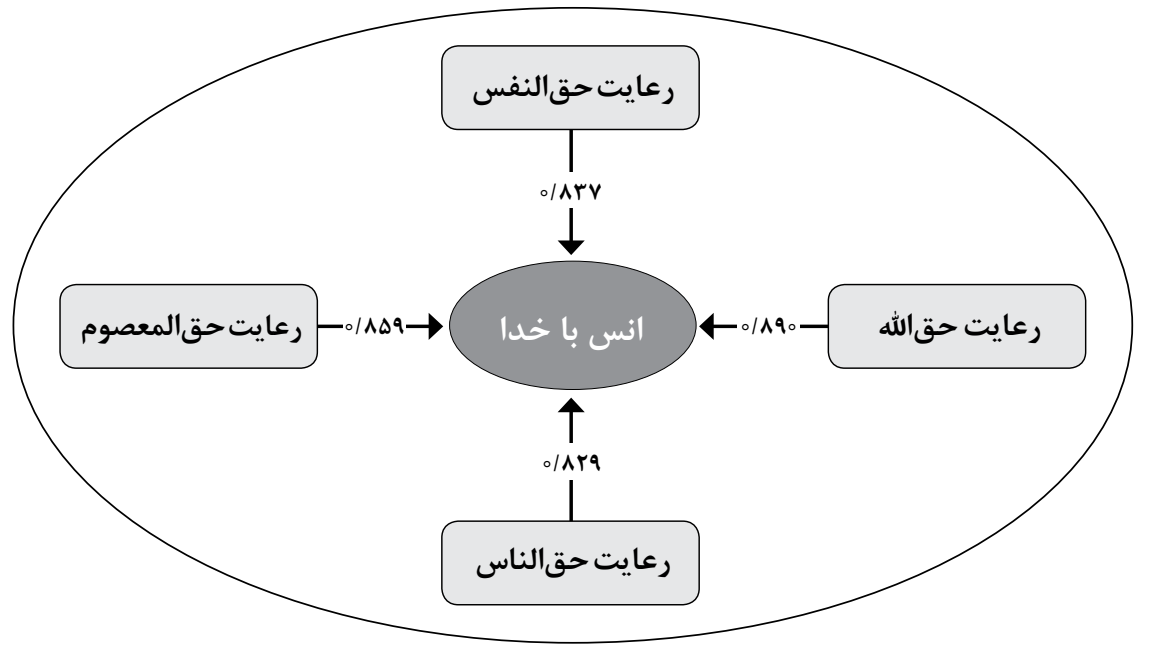

شكل ا. مؤلفههاى انعَيزهبش دعاى خمسهعشر بر انس دانش آموزان به خدا 


\section{بحث و نتيجلَيرى}

انســـان بهعنوان اشرف مخلوقات شايسته رسيدن به قرب الهى و انس با خداست كه اين امر در سايه تربيت درست و منطقى صورت مى گيرد. از طرفى، انسان نيازمند الكو و انكيزه است تا بتواند در مسير انس به خدا گام بردارد و براى رسيدن به قرب الهى بكوشد.

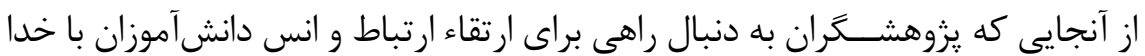
بودند، مؤلفههاى انخيزهبخش مناجات خمسهعشر را مورد مطالعه قرار دادند؛ جون هدف يزوهشخران شناسايى مؤلفههاى انكيزهبخش مناجات خمسهعشر بر انس دانشآموزان با خدا بود. نتايج اين مطالعه منجر به شناسايى جهار مؤلفه 》رعايت حقالنفس"، "رعايت

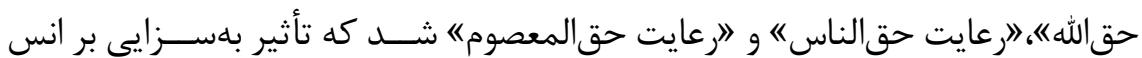
دانش آموزان به خدا دارند.

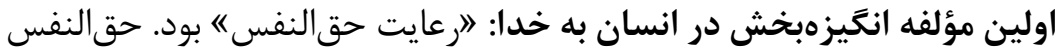
يكى از شوقانگيزترين حقوقى اســت كه امام سجاد (عليهالسلام) به شكلهاى مختلف در مناجات نورانى خود به آن اشــاره فرموده و نحوه رعايت آن را تبيين و شفافسازى كردهاند. يرهيز گارى و تقوا، توكل به خدا، دوستى و رفت و آمد با انسانهاى ســالم و مؤمن، دورى و اجتناب از آرزوهاى دور و دراز، دل بريدن از تعلقات دنياى فريبنده، صبر و شكيبايى در برابر سختىها، مشكلات و مصيبتها، اســتفاده درسـت و بهموقع از فرصتها و... از جمله حقوقى هستند كه هر كس بايد نســبت به رعايت آنها اهتمام بورزد. اين مؤلفه با توجه به بيشترين فراوانى مقولهها در مناجات خمسهعشــر بهعنوان اولين مؤلفه مورد مطالعه قرار زرفت. اما از نظر دانشآموزان ســومين رتبه را در انس آنها با خدا كســب كرده است.

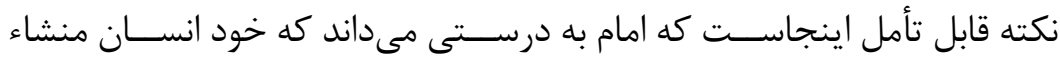
همه تحولات روحى و معنوى اوســت، لذا بيشترين تأكيد را بر اخوده يا رعايت

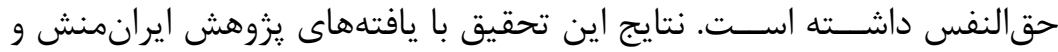

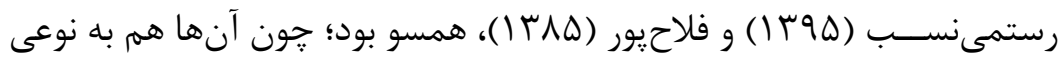
بـــه رعايت حقالنفس از جمله حفظ و تقويت عزت نفس و يرهيز از غفلت تأكيد 
دومين مؤلفه انگَيزهبخش در انســــان به خدا: 》رعايت حقالله بود. حق الله از ديخر حقوق گرانقدر و ارزشــمندى اســت كه رعايت آن بر هر انسان خداجويى واجب بوده كه امام زينالعابدين (عليهالسلام) بهطور احسن آن را مورد توجه قرار دادهاند. قدردانى از خـــداى مهربان به يُاس همه نعمتهاى زيبايش، بهره گيرى صحيح از نعمتهاى خداوند در تمــام امور زندگى، ايمان و يقين به قدرتهاى بى انتهاى خداوند بزرگ، عمل به همه تكاليف الهى يا واجبات، انديشــه و تأمل نســبت به همه نعمتهاى زيباى الهى و... از جمله مقولههايى اســت كه مورد توجه قرار كرفته اسـتـ. اين مؤلفه بيشــترين ســهمه را در انس دانش آموزان به خداى متعال كسـب نموده و در جايعاه اول قرار زرفته است. اين نشان از ياكى و سلامت فطرت در ســـنين نوجوانى است كه خدا را مسببالاسباب مىدانند و رعايــت حقالله را در بالاترين رتبه مــورد توجه قرار دادهاند كه اين به نوبه خود سرمايه بىنظيرى براى رشد، سعادت و تكامل فرد به حساب مى آيد. هــــومين مؤلفه انغَيزهبخش در انســــان به خدا: 》رعايت حق الناس" بود. اين مؤلفه از نظر دانشآموزان تهارمين رتبه را در انس به خدا كسب نموده است. حقالناس نيز از جمله حقوقى اســت كه حضرت علىبنالحسين (عليهالسلام) بهعنوان مربى آســمانى و الهى بشــريت، خود در عــــالى ترين سطح در فضا و شرايط حاكم عصر خويش عامل به آن بـــــوند و سيره ايشان جراغ راهى براى دورانهاى ضيق و سخت تاريخ است. حــــق ديخران از جمله حقوقى است كه ريشه در حقالله دارند و انســان در صورت يرورش صحيح فطرى جلوه صفات الهى را در خود محقق و تقويت مى كند. جنــان كـهـ قرآن كريهم تأكيد مى فرمايد حقالله ســادهتر، قابل عفو و غفران اســت و انســـان بايد امكان عبور از مسير حقالنــاس را خود فراهم كند؛ جراكه خداى متعال براى بند گكانش جنان عزت و احترامى قائل اســت كه حتى براى خود جنين حقى كه به جاى بنده ببخشد

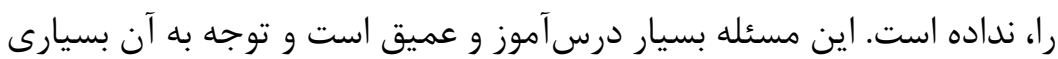
از گرمهاى زندگى بشر را رمزگشايى مى كند. خصوصاً رعايت آن ضمن تعليم و آموزش به نوجوانان تأثيرات شــرف تربيتى خواهد داشت. خيرخواهى و حفظ 
به ديخران، بخشــش و عفو ديخران، دورى از ســـوء ظن و بدَمانى به ديخران، گَشــاده رويى و برخورد نيكو با ديخران، روحيــهـه خدمت و مهرورزى، يرهيز از توهين، جلب توجه و جشمزيرانى، يرهيز از عداوت، نفاق، حسادت، خودنمايى و تكبر و... مقولههايى از جنس حقالناس اسـت كه در مناجات خمسهعشــر

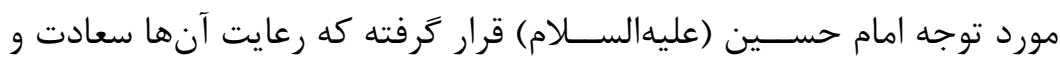
رشد انسان را در يَى دارد. جهارمين مؤلفه انگيزهبخش در انسان به خدا: "رعايت حقالمعصوم" بود. اين مؤلفه از نظر دانشآموزان دومين رتبه را در انس به خدا كســب نموده اســت. اطاعـت از معصومين در امور زندگى، توجه و توســل به امامان معصوم (ع) در تحقق حاجات، شـــاخت ائمه اطهــار بهويزَه امام زمان (ع)، اعتقاد راســخ به امامت، توجه به دعاها و زيارت امامان معصوم، درخواســت شفاعت از اهل بيت (ع) و... از جمله مقولههاى مربوط به رعايت حقالمعصوم اسـت كه از نظر امام مــورد توجه قرار گرفته اسـت. باز هم نكته قابل تأمسـل ديخرى وجود دارد كه

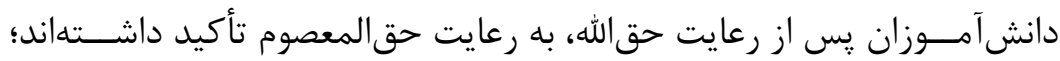
جون بهواســطه فطرت بىغل و غشى كه دارند به درســتى دريافتهاند كه اگر اطاعـت از خدا و معصومين رادر زندگى ســـرلوحه كارهاى خويش قرار دهند، نهتنهـــا به قرب الهى و انس به خدا دســت ريدا مى كنـند، بلكه به ســعادت و و

$$
\text { خوشبختى هم نائل مى }
$$

دومين يافته تحقيق نشــان داد كه هر يك از مؤلفههاى انخيزهبخش شناســايى

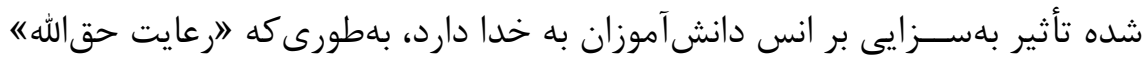

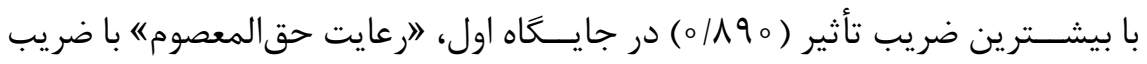

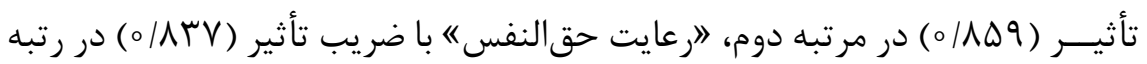
سوم و "رعايت حقالناس" با ضريب تأثير (AY9/ه) در جايگاه آخر قرار كرفته است. از آنجايى كه مؤلفههاى انخَيزهبخش انس انســان با خدا در مناجات خمسهعشــر ״رعايت حقالله"، "رعايت حق المعصوم"، "رعايت حقالنفس" و 》رعايت حقالناس"

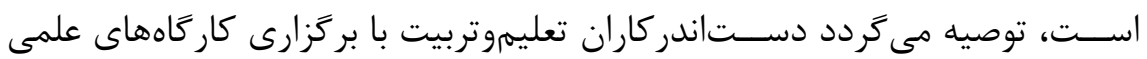

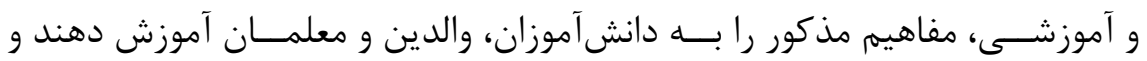


ســـح آكاهى آنها را متناســب با فرهنگ، ســن، جنس و تحصيلاتشان بالا ببرند

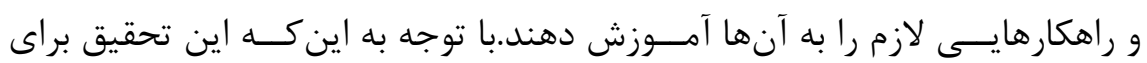

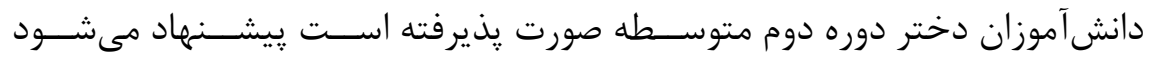

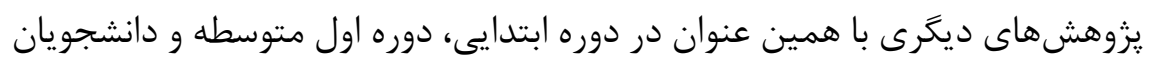

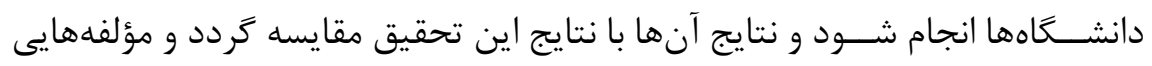

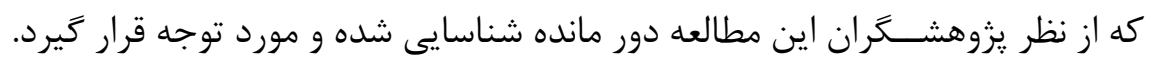

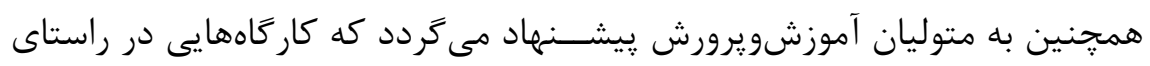

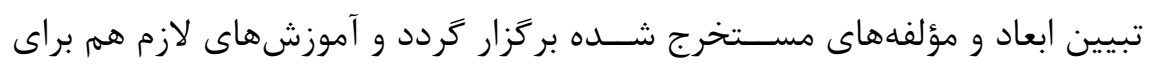

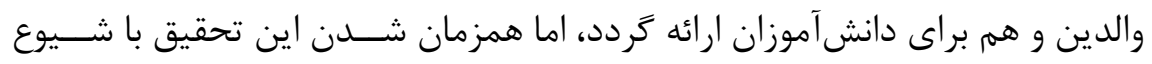

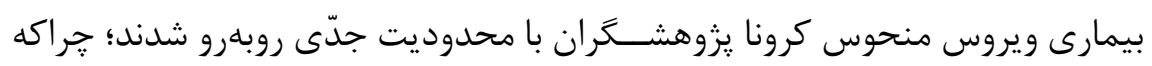

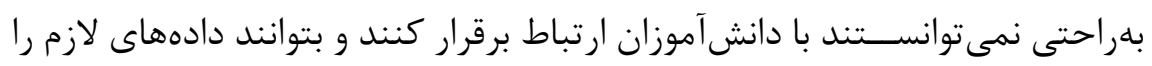
كردآورى نمايند.

\section{تشكُر و قدردانى:}

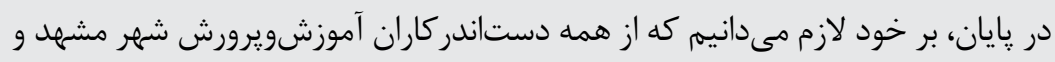

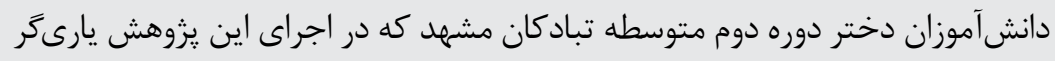
يُزوهشكَران بودند، نهايت سياس و قدردانى را به عمل بياوريم. 


\section{منابع}

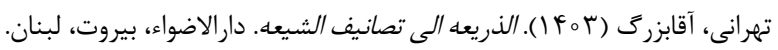

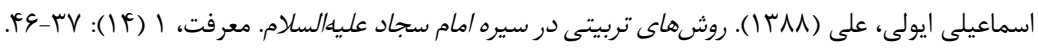

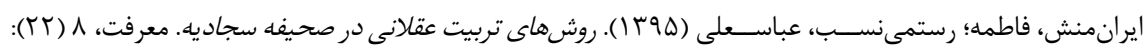
rاري-1

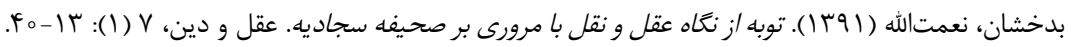

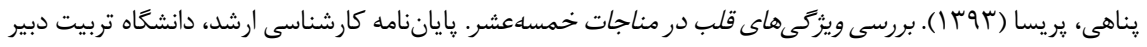
شهيد رجايى - دانشكده علوم انسانى. ترئ.

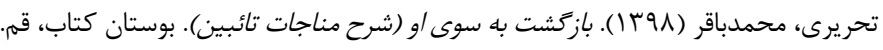

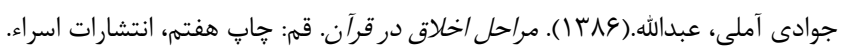

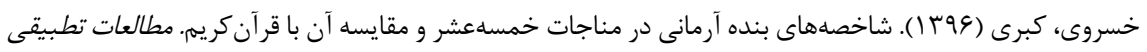

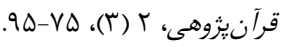

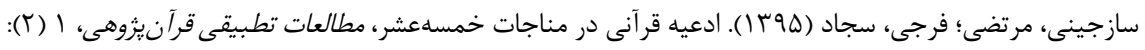
NQ-99

غرويان، محسن (rVY (I ). نكتهاى اخلاق و عرفان در مناجاتهاى سيد ساجدان. مؤسسه انتشارات نبوى، قم.

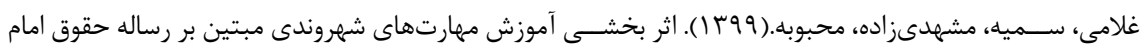

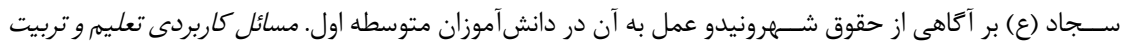

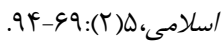

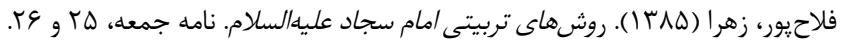

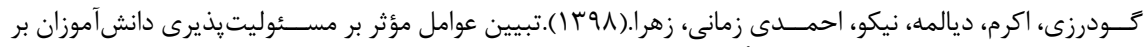

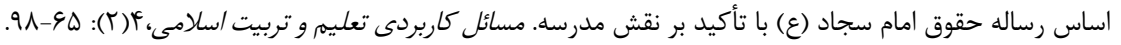

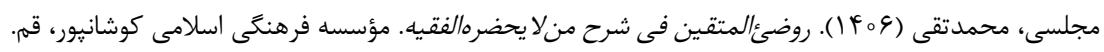

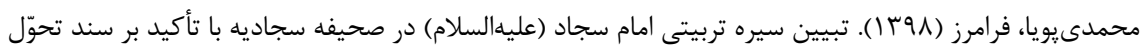

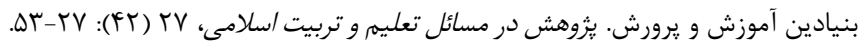

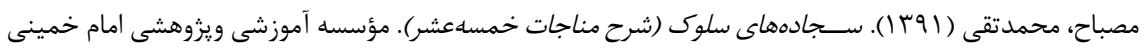
(0,0)، قم. 